\title{
Evaluation of the histology and the oxidative stress status in the placentas of obese mothers
}

\author{
Harith Ali* , Luma Al-Allaf** \\ *Postgraduate Student, Department of Anatomy, College of Medicine University of Mosul, \\ ${ }^{* *}$ Department of Anatomy, College of Medicine, University of Mosul, Mosul, Iraq \\ Correspondence: harithalali2019@gmail.com
}

(Ann Coll Med Mosul 2021; 43 (1):60-69).

Received: $13^{\text {th }}$ Augu. 2020; Accepted: $14^{\text {th }}$ Octo. 2020.

\begin{abstract}
Background: Obesity becomes one of the most universal medical problems that affects women at reproductive period.

Aim: To highlight the placental changes in obese mothers and to determine their relation to the oxidative stress.

Methods: This work is a prospective case- control study in which placentas were obtained from 60 singleton pregnant women who delivered at Al-Khansaa Maternity Teaching Hospital, Mosul, Northern of Iraq, starting from January 2020 to March 2020. The women were classified into three groups: Group 1: includes (control) women who have BMI ranged between $18-24.9 \mathrm{~kg} / \mathrm{m}^{2}(\mathrm{~N}=20)$, Group2: (Overweight) includes women who have BMI ranged between25-29.9 $\mathrm{kg} / \mathrm{m}^{2}(\mathrm{~N}=20)$, Group 3: (Obese) includes women with $\mathrm{BMI} \geq 30 \mathrm{~kg} / \mathrm{m}^{2}$ $(\mathrm{N}=20)$. Two placental biopsies were obtained from maternal side and fetal side of each case and submitted for histological examination via light microscope. In addition, Fresh placental specimens $(0.5 \mathrm{gm})$ had been taken from all study groups and frozen until the time of procedure for oxidative stress analysis.

Results: The Histological sections of group 2 and 3 placental discs revealed different histological changes in comparison with those of group 1 . These changes include syncytial knotting ,villous hypovascularity, villous fibrinoid necrosis, thickening of trophoblastic basement membrane, cytotrophoblastic hyperplasia, perivillous fibrin deposition, increase in number of nucleated red blood cells (NRBC), stromal fibrosis, chorangiosis ,paucity of vasculosyncytial membrane (VSM), villous edema, features of deciduitis, villitis, and increase the thickening of tunica media of the placental blood vessels. The biochemical analysis of the level of malondialdehyde (MDA) in the placental homogenates of the three study groups revealed a significant increase in homogenates of group 2 and 3 in comparison with that in group 1 indicating the presence of the oxidative stress.
\end{abstract}

Conclusion: this work reveals a marked increase in the level of MDA in placental homogenates of the obese and overweight groups in comparison with that of control group suggesting the role of the oxidative stress.

Keywords: Placenta, obesity, histological changes, oxidative stress.

$$
\begin{aligned}
& \text { تقييم النسيج و حالة الاجهاد التاكسدي لمشيمة الامهات اللواتي } \\
& \text { يعانين من السمنة }
\end{aligned}
$$

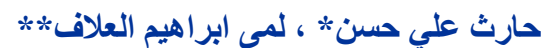

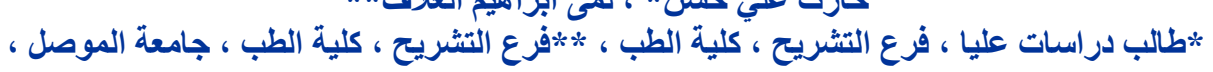

$$
\begin{aligned}
& \text { الموصل ، العراق ، المرع المات }
\end{aligned}
$$

الخلفية: السمنة هي واحدة من أكثر الششاكل الطبية انتشار التي تؤثر على الإنجاب و التي لها نتائج سلبية معقدة على الام والطفل

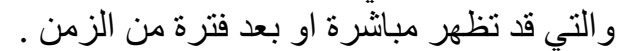

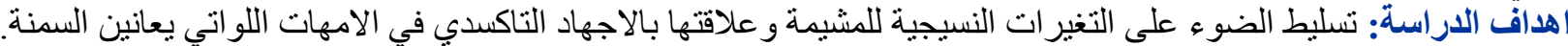

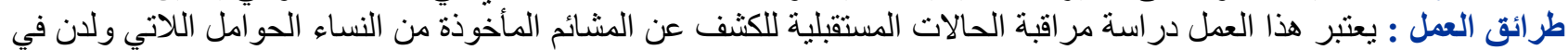

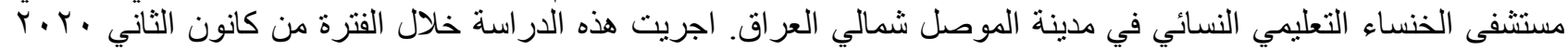




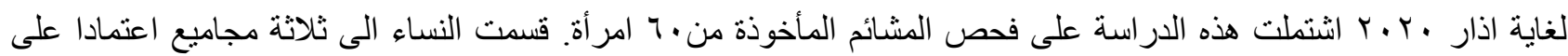

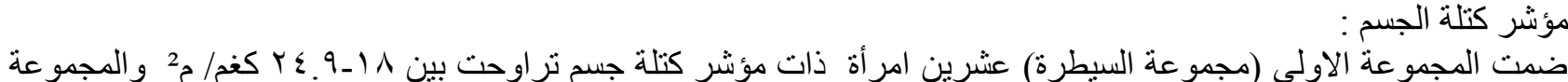

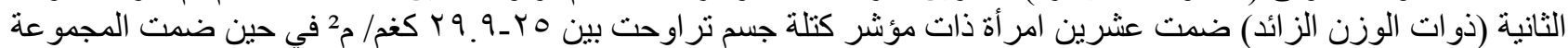

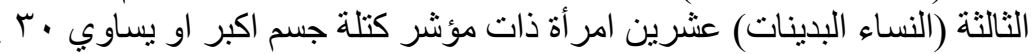

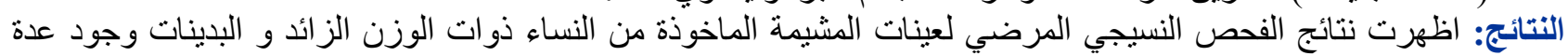

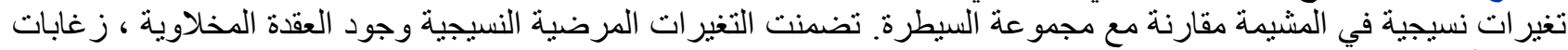

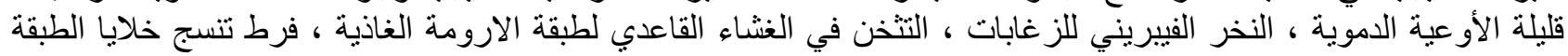

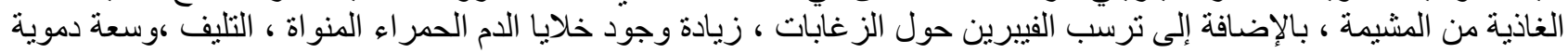

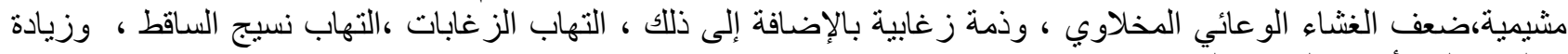
سمك غلالة الأو عية الدموية المثنيمية.

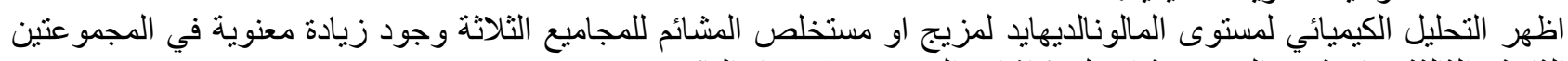

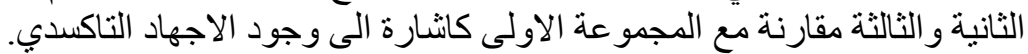

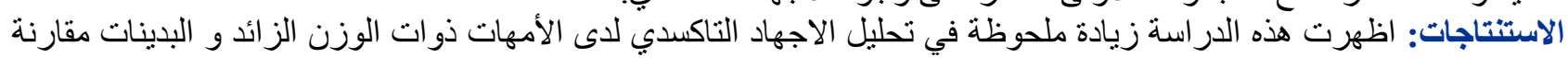
بمجمو عة السيطرة..

الكلمات المفتاحية: المشيمة، السمنة، التغيرات النسيجية ،الاجهاد التاكسدي.

\section{INTRODUCTION}

$\mathrm{M}$ aternal obesity has a significant relation with an increased risk of adverse maternal and fetal outcome. It also has an effect on mother and her family psychologically and financially.Optimization of women weight is essential for a good pregnancy outcome and it is important to maintain a healthy life for mother and baby as well as to keep the familial unity.

Obesity is usually measured as a ratio between a body weight to height and identified as body mass index, ${ }^{1}$ which is directly related with the amount of fat in the body.

Obesity is defined as a body mass index (BMI) $\geq 30 \mathrm{~kg} / \mathrm{m}^{2}$. $2-4$

The presence of excessive amount of adipose tissue produces a significant quantity of pro inflammatory cytokines as Interleukin 6(IL 6), adipokinin and Tumor necrotic factor alpha (TNF alpha) as well as, hormones such as adiponectin and leptin in dysregulated manner that lead to insulin resistance and inflammation. ${ }^{5}$ Moreover, there is an increase in infiltration of macrophages and expressing inflammatory markers which may lead to maternal systemic inflammation. ${ }^{6}$

In addition, maternal obesity has an impact on placental metabolism and fetal redox balance. Changes in cortisol level, hypoxia, nitrative and oxidative stress may precipitate in fetal metabolic programming of the metabolic syndrome ${ }^{7}$.

Oxidative stress reflects the disturbance in the balance between the systemic indicator of reactive oxygen species (ROS) and the ability of biological system to repair the consequential damage or reactive intermediates detoxification. ${ }^{8}$ Although (ROS) can be helpful (the immune system used them as a method to attack and destruction of pathogens), ${ }^{9}$ but the creation of free radicals and peroxides due to disturbances in the normal cells redox state will cause toxic effects and damage to all cell components. ${ }^{8}$ Oxidative stress is assumed to be implicate in the development of myocardial infarction ,Parkinson's disease, atherosclerosis, cancer, heart failure, Alzheimer's disease, autism. ${ }^{9}$

There are numerous oxidative biomarkers, one of them is the malondialdehyde which is an organic substance produced by lipid peroxidation when lipid was degenerated by oxidation. ${ }^{10}$

The reports on the histological changes of placentas in obese mothers and even their relation -if present- to the oxidative stress status has not been studied well yet. So, this study tried to highlight the effect of obesity on the placental oxidative stress and to determine its effect on the placental histology.

\section{Subjects, materials and methods}

This is a prospective case-control study that had examined placentas which were obtained from 60 singleton pregnant women who delivered at ALKhansaa Maternity Teaching Hospital in Mosul province in north of Iraq, starting from $1^{\text {st }}$ of January 2020 to $1^{\text {st }}$ of March 2020. Ethical approval was obtained from Committee of Ethics at Nineva Health Directorate, Mosul, Iraq. Subject's history was obtained from every woman, their gestational age was calculated using the last menstrual period and/ or the early ultrasonographic examination report. Pregnant women with nongestational diabetes mellitus, essential hypertension, placental abruption, multiple 
pregnancy, smoking and Rhesus negative blood group were excluded.

Body mass index (BMI) of each mother was calculated by dividing the weight in $(\mathrm{Kg})$ by height in square meter $\left(\mathrm{m}^{2}\right)$. The weight was obtained according to Davis et al. by subtracting $12.5 \mathrm{~kg}$ from the current weight. 4,11

According to their $\mathrm{BMI}$, the women were classified into three groups as the follows:

1.Group1:(control group) which includes 20 women with BMI ranged between $18-24.9 \mathrm{~kg} / \mathrm{m}^{2}$

2.Group2:(over weight group) which includes 20 women with BMI ranged between $25-29.9 \mathrm{~kg} / \mathrm{m}^{2}$

3. Group3:(obese group) which includes 20 women with $\mathrm{BMI} \geq 30 \mathrm{~kg} / \mathrm{m}^{2}$.

Two biopsies of placental tissue were obtained, from maternal side (decidua) and fetal side (chorionic plate), and were prepared for histological examination after staining with (H\&E) using light microscope. ${ }^{12-14}$ While analysis of the oxidative stress parameter (MDA) was done as follows: ${ }^{15,16}$

Fresh placental specimens $(0.5 \mathrm{gm})$ were taken from all groups involved in this study and were frozen until the time of procedure of biochemical analysis. Each specimen was applied in inspection tube of homogenizer device, then cold Tris-EDTA buffered solution $(10 \mathrm{ml})$ was added, then was put in centrifuge for $15-60$ seconds within each accelerated speed from 400- 1100 round per minute (rpm.), then $0.5 \mathrm{ml}$ of homogenizer solution was mixed with $0.5 \mathrm{ml}$ of cooled peroxidation solution in a test tube with well shaking, then was put in water bath for half an hour at $73^{\circ} \mathrm{C}$. After that the reaction of peroxidation was stopped via addition of $0.5 \mathrm{ml}$ of sodium arsenate that was dissolved in trichloroacetic acid and was put in the centrifuge for $5 \mathrm{~min}$. at $3000 \mathrm{rpm}$. Then it was filtrated and $1 \mathrm{ml}$ of the filtrate was put in another test tube. Adding of $0.25 \mathrm{ml}$ of both thiobarbituric acid (TBA) and distilled water was done with well shaking. Then transferring it to water bath for 15 $\min$ at $100^{\circ} \mathrm{C}$. Using spectrophotometer, the absorbance of each sample of all study groups was read twice, firstly at 532 nanometer $(\mathrm{nm})$ and after 15 mints. at $453 \mathrm{~nm}$.

Statistical analysis of data was done using excel program and statistical package for social sciences (SPSS) version 3. To compare the frequencies of different placental lesions between two groups, chi square $\left(x^{2}\right)$ was used, where $P$ value $<0.05$ was considered as significant. ${ }^{17}$

\section{RESULTS}

This study has examined placentas from 60 women who were categorized into three groups.

The light microscopical examination of sections obtained from the fetal surface of placental disk of control group (Group1) ,using H\&E preparation ,showed that each chorionic villous appeared as a vascular stroma lined or covered with multinucleated syncytiotrophoblastic layer with indistinct cell boundaries and dark stained nuclei with occasional inconspicuous cytotrophoblastic cells (Figure 1). While the microscopical examination of sections of the maternal surface of this group showed normal appearance of maternal decidual cells (Figure 2).

On the other hand, the present study revealed that the histopathological examination of placental sections obtained from overweight mothers (Group 2) and obese mothers (Group 3) showed several placental changes compared to those of control group. Table 1.

The most frequent feature among these sections is the presence of syncytial knotting in $3(15 \%)$ out of 20 placentas of group 2 and $13(65 \%)$ out of 20 placentas of group 3 (Figure 3 ). In addition, features of hypovascular villi are noticed in $4(20 \%)$ in sections of group 2 and $10(50 \%)$ of group 3 sections (Figure 3).

Moreover, villous fibrinoid necrosis occurred in 3 (15\%) placental sections of overweight mothers while it occurs in $10(50 \%)$ of placental sections of obese mothers (Figure 4), while thickening of trophoblastic basement membrane occurred in 2 (10\%) of group 2 and 9 (45\%) of group 3 sections. (Figure 4).

Also, the histopathological examination of placental sections obtained from overweight mothers (group 2) revealed presence of perivillous fibrin deposition which appeared in $4(20 \%)$ whereas in obese group it appeared in 10 (50\%) (Figure 5). Features of stromal fibrosis were noticed in $(40 \%)$ of obese sections (Figure 5). In addition cytotrophoblastic hyperplasia occurs in 2 $(10 \%)$ of group 2 sections and in $8(40 \%)$ of group 3 sections (Figure 6).

The present study revealed that the histopathological examination of placental sections obtained from overweight mothers (group2) showed presence of nucleated red blood cells (NRBC) in fetal capillaries and this finding was identified in 4 (20\%) while it occurred in 7 (35\%) of the obese group sections. (Figure 6), while features of chorangiosis was found in $1(5 \%)$ in group 2 and $4(20 \%)$ of group 3 sections. (Figure 6). 
On the other hand, paucity of vasculosyncytial membrane VSM was found in $15 \%$ of overweight sections while it occurred in $35 \%$ of sections of obese mothers. (Figure 6).

Features of villous edema were shown in $2(10 \%)$ out of 20 sections of overweight mothers and in 4 $(20 \%)$ of obese group sections. (Figure 7 ). This study observed features of villitis in $1(5 \%)$ in overweight group and $4(20 \%)$ out of 20 placental sections of obese mothers. (Figure 8), while deciduitis was noticed in $4(20 \%)$ in group 2 and $7(35 \%)$ of group 3 sections. (Figure 8 ).

This work reveals thickening of tunica media of placental vessels in $2(10 \%)$ of group 2 and 5 (25\%) of group 3 (Figure 9 ).

Analysis of oxidative stress (MDA level):

The mean concentration of MDA in placental homogenates of all study groups revealed that level of MDA in obese group was $2.46 \pm 0.06 n$ $\mathrm{mol} / \mathrm{gram}$, while MDA concentration in control group was $0.55 \pm 0.05 \mathrm{n} \mathrm{mol} / \mathrm{gram}$. On the other hand, the level of MDA concentration in homogenates of overweight group was $1.55 \pm 0.24$ $\mathrm{n} \mathrm{mol} / \mathrm{gram}$. Table 2. Histogram 1.

Table 1. Histological finding of placentas in all study groups.

\begin{tabular}{|c|c|c|c|}
\hline $\begin{array}{l}\text { GRQUPS } \\
\text { Oxidative } \\
\text { stress }\end{array}$ & $\begin{array}{l}\text { Control } \\
\text { group } \\
\text { Mean } \pm \\
\text { SE }\end{array}$ & $\begin{array}{l}\text { Overweight } \\
\text { group } \\
\text { Mean } \pm \text { SE }\end{array}$ & $\begin{array}{l}\text { Obese } \\
\text { group } \\
\text { Mean } \pm \\
\text { SE }\end{array}$ \\
\hline $\begin{array}{l}\text { MDA } \\
\text { concentration } \\
n \text { mol/gram } \\
\text { tissue }\end{array}$ & $\begin{array}{l}0.55 \pm \\
0.05 \mathrm{a}\end{array}$ & $\begin{array}{l}1.55 \pm 0.24 \\
b\end{array}$ & $\begin{array}{l}2.46 \pm \\
0.06 \mathrm{c}\end{array}$ \\
\hline
\end{tabular}

The rows with similar letters mean no significant difference among groups ( $p \leq 0.05$ )

The rows with different letters mean significant difference among groups ( $\leq \leq 0.05)$
Table 2. The level of MDA in placental homogenates of the three study groups.

\begin{tabular}{|c|c|c|c|}
\hline $\begin{array}{l}\text { Groups } \\
\text { Histological } \\
\text { finding }\end{array}$ & $\begin{array}{l}\text { Group } \\
\text { 1( Contro } \\
\text { I) } \\
\mathrm{N}=20 \\
\text { No. }(\%)\end{array}$ & $\begin{array}{l}\text { Group } 2 \\
\text { (overweigh } \\
\text { t) } \mathrm{N}=20 \\
\text { No. }(\%)\end{array}$ & $\begin{array}{l}\text { Group } \\
3 \text { ( Obes } \\
\text { e) } \\
\mathrm{N}=20 \\
\text { No. }(\%)\end{array}$ \\
\hline $\begin{array}{l}\text { Syncytial } \\
\text { knotting }\end{array}$ & $\begin{array}{l}2(10 \%) \\
a\end{array}$ & $\begin{array}{l}3(15 \%) \\
b\end{array}$ & $\begin{array}{l}13 \\
(65 \%) \\
c\end{array}$ \\
\hline $\begin{array}{l}\text { Hypovascular } \\
\text { villi }\end{array}$ & $\begin{array}{l}1(5 \%) \\
a\end{array}$ & $\begin{array}{l}4(20 \%) \\
b\end{array}$ & $\begin{array}{l}10 \\
(50 \%) \\
c\end{array}$ \\
\hline $\begin{array}{l}\text { Villous } \\
\text { fibrinoid } \\
\text { necrosis } \\
\end{array}$ & $\begin{array}{l}1(5 \%) \\
a\end{array}$ & $\begin{array}{l}3(15 \%) \\
a\end{array}$ & $\begin{array}{l}10 \\
(50 \%) \\
b\end{array}$ \\
\hline $\begin{array}{l}\text { Thickening of } \\
\text { trophoblastic } \\
\text { basement } \\
\text { membrane }\end{array}$ & $\begin{array}{l}1(5 \%) \\
a\end{array}$ & $\begin{array}{l}2(10 \%) \\
a\end{array}$ & $\begin{array}{l}9(45 \%) \\
b\end{array}$ \\
\hline $\begin{array}{l}\text { Cytotrphoblas } \\
\text { tic } \\
\text { hyperplasia }\end{array}$ & $\begin{array}{l}0(0 \%) \\
a\end{array}$ & $\begin{array}{l}2(10 \%) \\
b\end{array}$ & $\begin{array}{l}8(40 \%) \\
c\end{array}$ \\
\hline $\begin{array}{l}\text { Perivillous } \\
\text { fibrin } \\
\text { deposition }\end{array}$ & $\begin{array}{l}1(5 \%) \\
a\end{array}$ & $\begin{array}{l}4(20 \%) \\
b\end{array}$ & $\begin{array}{l}10 \\
(50 \%) \\
c\end{array}$ \\
\hline $\begin{array}{l}\text { Nucleated } \\
\text { RBCs }\end{array}$ & $\begin{array}{l}1(5 \%) \\
a\end{array}$ & $\begin{array}{l}4(20 \%) \\
b\end{array}$ & $\begin{array}{l}7(35 \%) \\
\mathrm{c}\end{array}$ \\
\hline $\begin{array}{l}\text { Stromal } \\
\text { fibrosis }\end{array}$ & $\begin{array}{l}0(0 \%) \\
\mathrm{a}\end{array}$ & $\begin{array}{l}1(5 \%) \\
a\end{array}$ & $\begin{array}{l}8(40 \%) \\
b\end{array}$ \\
\hline Chorangiosis & $\begin{array}{l}1(5 \%) \\
a\end{array}$ & $\begin{array}{l}1(5 \%) \\
a\end{array}$ & $\begin{array}{l}4(20 \%) \\
b\end{array}$ \\
\hline $\begin{array}{l}\text { Paucity of } \\
\text { VSM }\end{array}$ & $\begin{array}{l}1(5 \%) \\
a\end{array}$ & $\begin{array}{l}3(15 \%) \\
b\end{array}$ & $\begin{array}{l}7(35 \%) \\
\mathrm{C}\end{array}$ \\
\hline Villous edema & $\begin{array}{l}1(5 \%) \\
a\end{array}$ & $\begin{array}{l}2(10 \%) \\
b\end{array}$ & $\begin{array}{l}4(20 \%) \\
C\end{array}$ \\
\hline Villitis & $\begin{array}{l}0(0 \%) \\
\mathrm{a}\end{array}$ & $\begin{array}{l}1(5 \%) \\
b\end{array}$ & $\begin{array}{l}4(20 \%) \\
c\end{array}$ \\
\hline Deciduitis & $\begin{array}{l}1(5 \%) \\
a^{2}\end{array}$ & $\begin{array}{l}4(20 \%) \\
b\end{array}$ & $\begin{array}{l}7(35 \%) \\
\mathrm{c}\end{array}$ \\
\hline $\begin{array}{l}\text { Thickening of } \\
\text { tunica media } \\
\text { of vessels }\end{array}$ & $\begin{array}{l}1(5 \%) \\
a\end{array}$ & $\begin{array}{l}2(10 \%) \\
b\end{array}$ & $\begin{array}{l}5(25 \%) \\
c\end{array}$ \\
\hline
\end{tabular}

The rows with similar letters mean no significant difference among groups ( $p \leq 0.05)$

The rows with different letters mean significant difference among groups ( $p \leq 0.05)$ 


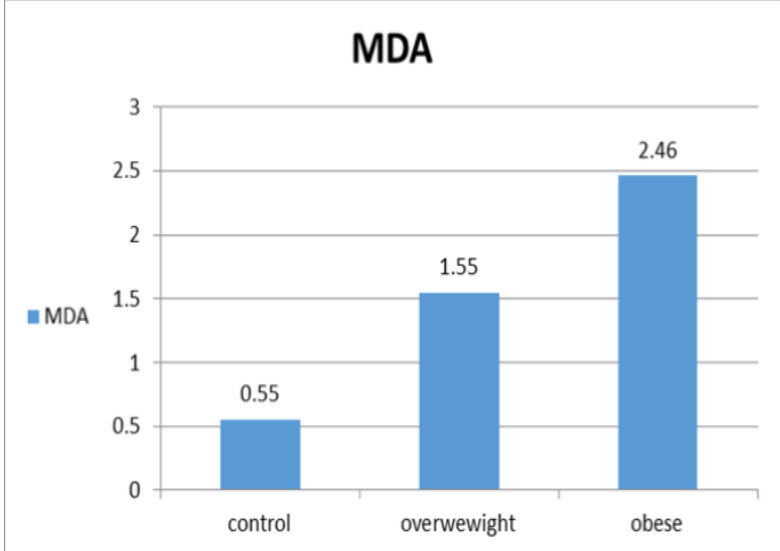

Histogram 1. The value of MDA concentration in placental homogenates of the three study groups.

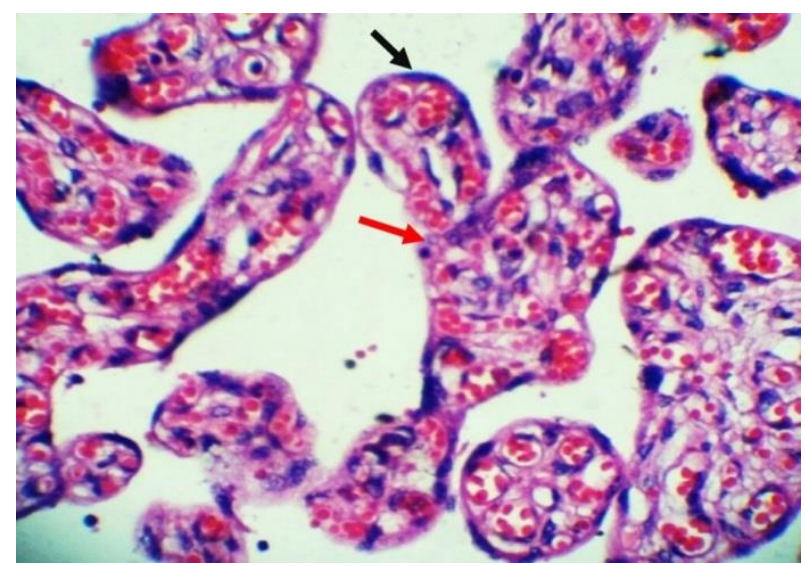

Figure 1. A photomicrograph of a placental tissue obtained from control group with normal villous architecture. The vascular stroma lined with multinucleated syncytiotrophoblastic layer with indistinct cell boundaries and dark stained nuclei (black arrow) with occasional cytotrophoblastic cells (red arrow) (H\&E×250).

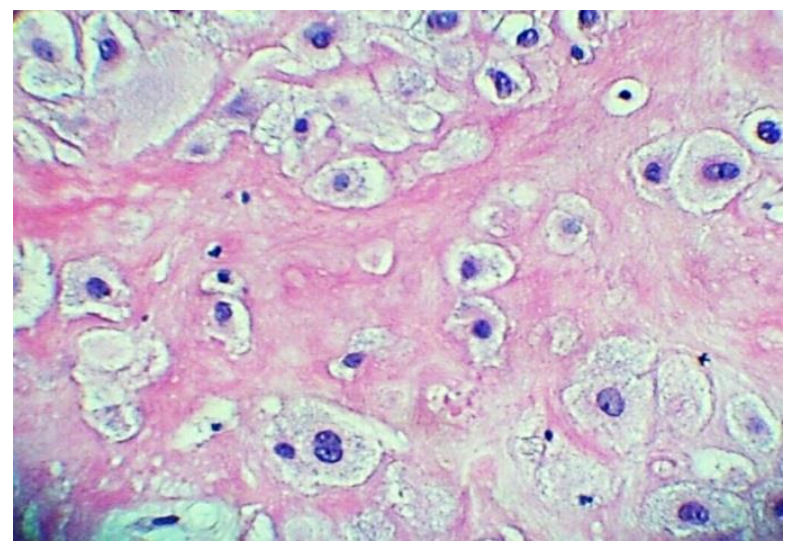

Figure 2. A photomicrograph of a placental tissue obtained from a woman of control group with normal decidual architecture $(H \& E \times 400)$.

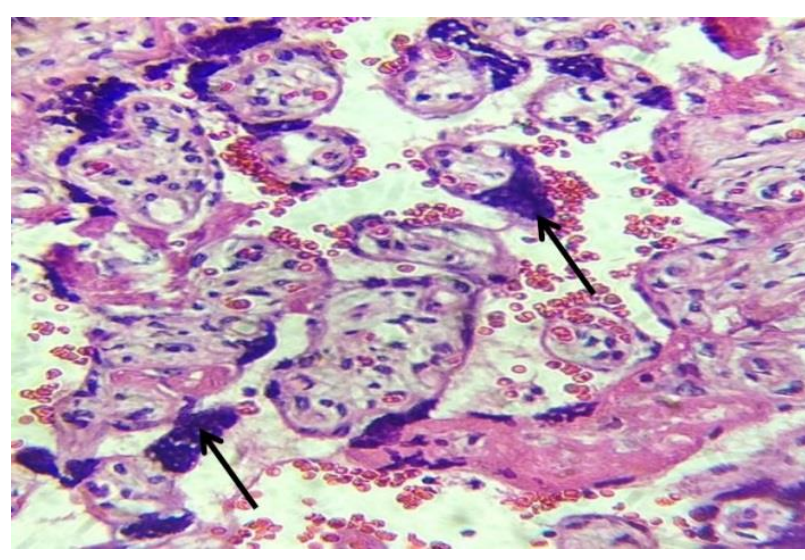

Figure 3. A photomicrograph of a placental tissue obtained from a woman of overweight group with features of hypovascularity and syncytial knotting (arrow). (H \&E×400).

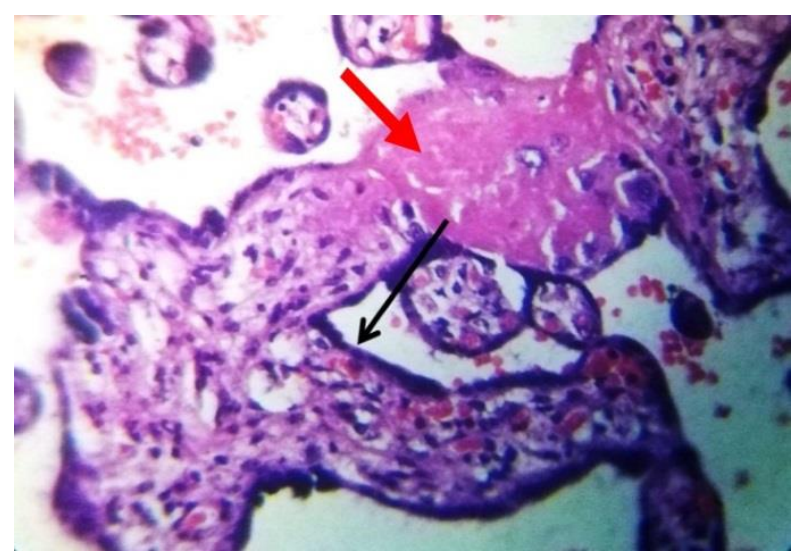

Figure 4. A photomicrograph of a placental tissue obtained from an obese woman showing villous with thickening of basement membrane (arrow) and fibrinoid necrosis(red arrow) (H\&E×400).

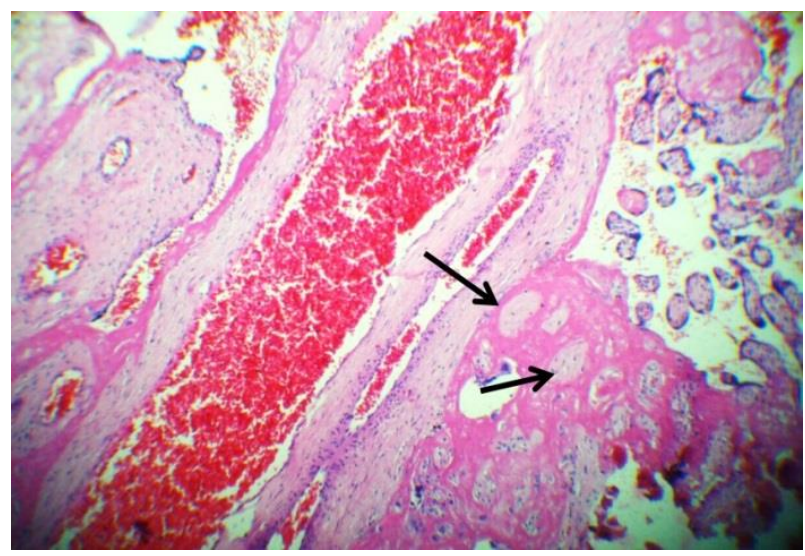

Figure 5. A photomicrograph of a placental tissue obtained from a woman of the obese group .Fibrotic avascular villi are embedded in a sea of fibrin (perivillous fibrin deposition) (arrows). $(H \& E \times 160)$. 


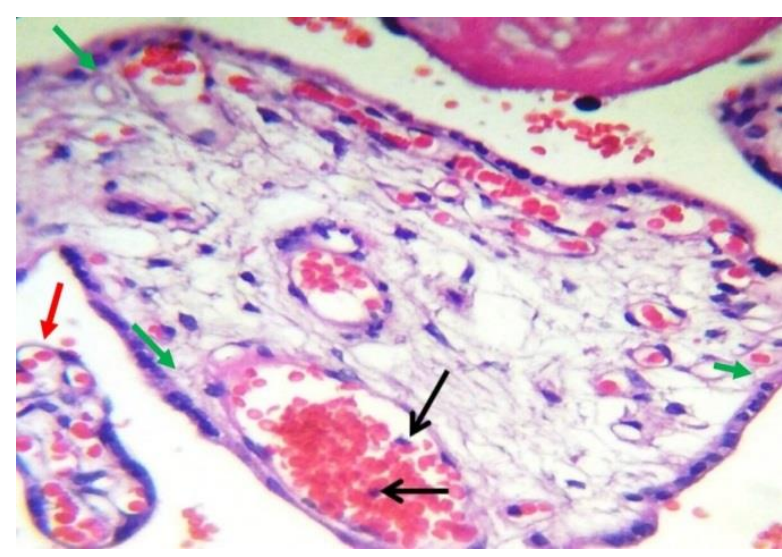

Figure 6. A photomicrograph of a placental tissue obtained from a woman of overweight group with features of nucleated red blood cells (arrows) with cytotrophoblastic hyperplasia (green arrows) , chorangiosis and paucity of VSM (red arrow) (H\&E×400).

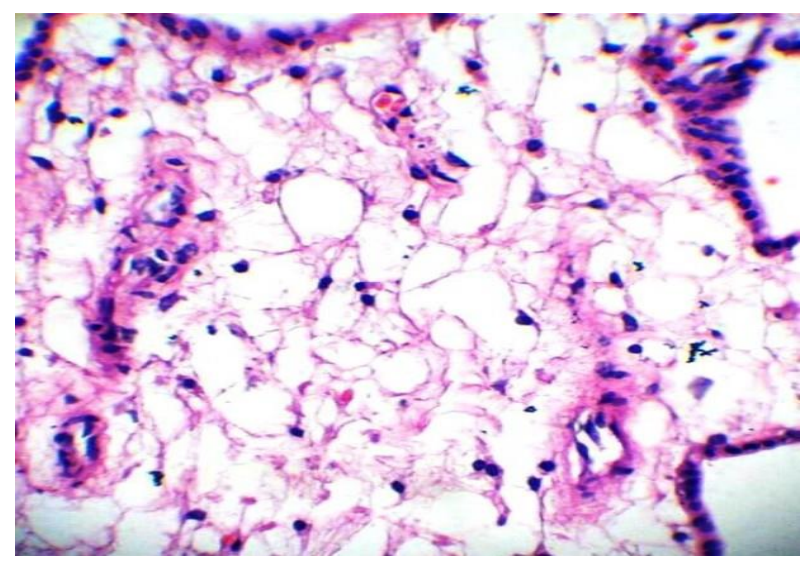

Figure 7. A photomicrograph of a placental tissue obtained from an obese mother. Villous edema is noticed. (H\&E×400).

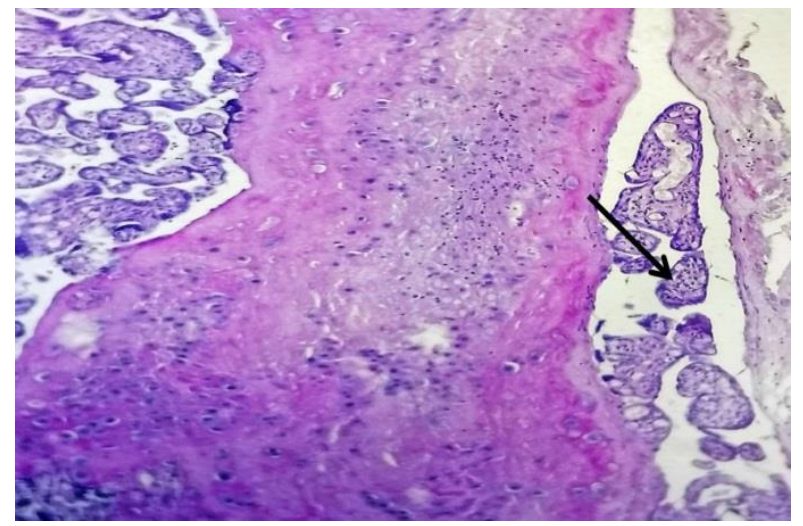

Figure 8. A photomicrograph of a placental tissue obtained from a woman in the overweight group. Features of deciuitis and villitis (arrow) are seen (H\&Ex160).

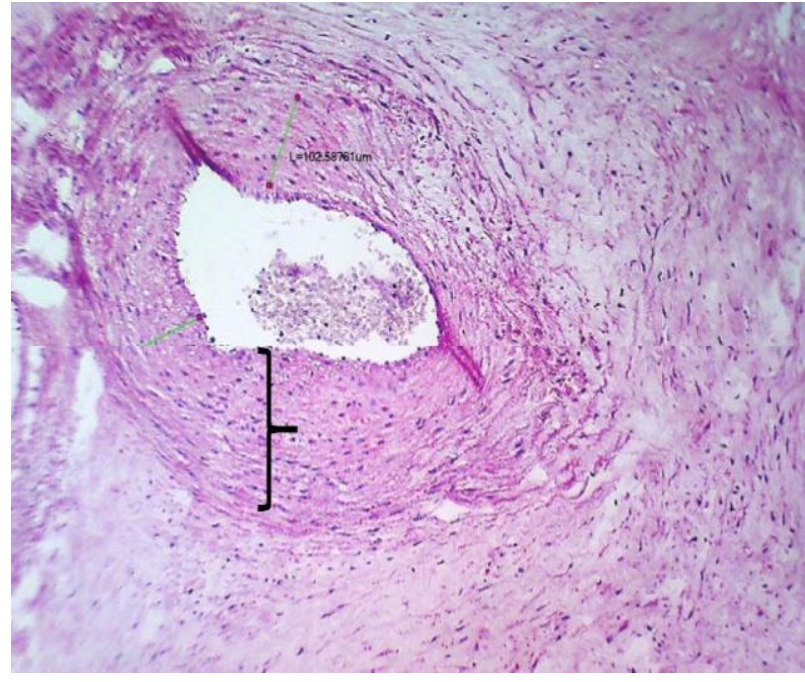

Figure 9.A photomicrograph of a placental tissue obtained from obese group with an increase in the thickening of tunica media of placental vessels (black bracket). (H\&E×100)

\section{DISCUSSION}

Practically, pathology of placenta is totally became an identical specialty after years of uncertainty due to different views of experts. Pathologists, with different interests and training skills. Found that there is closely relationship of placental histological lesions with clinical features in both mothers and fetal outcomes. ${ }^{18}$

The microscopical examination of placentas that enrolled in this work identified several histological lesions among placentas of obese and overweight groups in comparison with those of control.

Among these lesions, a significant increase in the frequencies of syncytial knots was noted in placentas of obese group and overweight group compared with those of control. Such finding was consistent with Huppertz study in 2008 who considered the syncytial knots as a placental adaptive response.

In addition, this study revealed a significant increase in the thickening of trophoblastic basement membrane in placentas of obese group, a finding that also related to placental hypoxia.

Gill et al. in 2011 and Sankar et al. in 2012 reported that any increase in the thickening of trophoblastic basement membrane leads to reduction of placento-fetal blood circulation and accumulation of syncytial knots. ${ }^{20,21}$

Another striking feature that have been shown in current work was presence of a significant number of hypovascular villi in placentas of obese and overweight mothers in comparison with those of control group. The hypovascular villi are defined as the villi that contain small non-dilated capillaries in 
their stroma and sometimes devoid of capillaries. ${ }^{22}$ This finding is in accordance with that of Hayward et al. in 2013, who was attributed that to the frequent abnormal spiral arteries modifications and alteration of placental vascular function. ${ }^{22}$

The villous fibrinoid necrosis was found significantly in placentas of obese mothers when compared with those of overweight and control groups. Benirscheke and Kaufmann in 2000 described that this lesion may result from several coagulation cascades after injury of syncytiotrophoblasts. ${ }^{23}$

In fact, this study revealed that syncytial injury was observed in placental sections of obese mothers when compared to those of control group. $^{24}$

The four preceding histological lesions (syncytial knots, hypovascular villi, thickening of trophoblastic membrane, and villous fibriniod necrosis) are encompassed under umbrella of accelerated villous maturation (AVM), Which occurs as a result of maternal vascular malperfusion, and abnormal flow of spiral artery that is characterized by high velocity and low volume maternal blood. ${ }^{(18)}$ AVM is represented by short hypovascular villi with increased intervillous fibrin, and syncytial knots in addition with increasing thickness of trophoblastic basement membrane.

AVM was found in the placentas of obese and overweight women. ${ }^{13,25}$

In fact, AVM may be due to the placental angiogenesis as a result of hypoxia and placental insufficiency. 26

Moreover, this study reveals a significant increase of cytotrophoblastic hyperplasia in placental sections of women in obese group and overweight group in comparison with women of control group. Cytotrophoblastic cells normally disappear in term placenta of non-complicated pregnancies. Persistence of cytotrophoblastic cells partially occurs due to hypoxial condition in placental tissue in complicated pregnancies such as maternal diabetes, Rhesus incompatibility, preeclampsia, and fetal growth restriction. ${ }^{27-29}$

This study revealed a significant elevation of number of nucleated red blood cells (NRBCs) in fetal capillaries of placentas in obese and overweight groups in contrast to those of control group. In fact, NRBCs are rarely appeared. This finding is similar to that of Rincon et al. in 2019, who found that the erythropoietin value and NRBCs are higher in newborns of obese and overweight mothers compared with mothers who have normal BMI. These findings may ensure the theory that the increased pregnant BMI may result in intrauterine hypoxemia. 30,31

The delayed villous maturation (DVM) including (chorangiosis, paucity of VSM and stromal fibrosis). ${ }^{18}$ DVM was frequent in obese and overweight women compared to women who have normal BMI. This finding was consistent with those of previous reports. ${ }^{32,33}$, this lesion is attributed to the insulin resistance and hypoxia. Insulin resistance was more frequent in obese women which lead to increased proliferation of villi in early gestation period that lead to increased placental stroma and decreased numbers of vasculosyncytial membrane (VSM) layers with increase in its thickness. The thickness of VSM was gradually reduced which is necessary to ensure placental function in the final stage of pregnancy. 34,35

This study revealed a significant increase in villous edema in sections of overweight and obese groups in comparison with those of control group. This lesion may be a result of fetal vascular malperfusion and weak blood circulation in the villous tree. Rosaddo-yepez et al. in 2019 revealed a high occurrence of villous edema in sections of placentas of obese women. ${ }^{36}$ This lesion comprises insufficient fetal vascular perfusion and is related to an increase in the morbidity of neonates. ${ }^{37}$ Villous edema may cause either fetal anemia, CNS injury or perinatal death, ${ }^{38}$ also it is correlated with severe term fetal acidemia. $^{39}$

This study revealed a marked increase in the frequency of deciduitis and villitis in placentas of obese and overweight women. Deciduitis and villitis are defined as an infiltration of large number of lymphocytes, neutrophils and macrophages in decidual and villous tissue. These findings were in agreement with those of other studies, which reported a strong relation between obesity of women with increased placental expression to chemotactic cytokines. ${ }^{35,40}$ in addition, Denison et al. in 2010 revealed the relation between obesity and inflammation of placenta, and an increase in the pro-inflammatory cytokines in mother circulation. 41 Obesity makes a physiologic condition of low-grade chronic inflammation with increased level of inflammatory circulating markers such as CRP, IL-6, IL-8 and TNF- $\alpha$. These markers were related with metabolic dysregulation, diabetes and atherogenesis. ${ }^{42}$

The biochemical analysis of the placental homogenates of three study groups was performed in order to clarify the role of oxidative stress in the placental insufficiency of obese and overweight mothers in comparison with that of control. Level of MDA was measured in the placental homogenates of different groups. There was a significant elevation in the concentration of MDA in homogenates of placentas in groups of obese and overweight women when compared to that of control group. This result is similar to that of Malti 
and Nace in 2014, they reported an inequality of status between oxidants and antioxidants. ${ }^{43,44}$

Moreover, Myatt and Cui in 2004 proposed that the oxidative stress in placentas of obese mothers is counteracted by antioxidant property. 45

Pro inflammatory cytokines elevation and greater production of reactive nitrogen and oxygen species as a result of increased fatty acids may reduce the function of mitochondria. ${ }^{46}$ Which in turn affects mitochondrial fatty acid oxidation. ${ }^{47}$ On the other hand, mitochondrial function may play a role in controlling of many cellular actions such as cellular signaling and apoptosis. ${ }^{48}$

This study shows several lesions such as villitis, deciduitis, AVM, elevation in number of NRBCs and perivillous fibrin deposition, all may lead to oxidative stress. ${ }^{42}$ At the same time these findings may be attributed to oxidative stress. Inflammatory conditions as well may cause oxidative stress, lipid peroxidation, and damage of protein and DNA which subsequently lead to cell death. ${ }^{49-51}$

In conclusion, this work reveals a marked increase in the level of MDA in placental homogenates of the obese and overweight groups in comparison with that of control group suggesting the role of the oxidative stress. In addition, The placental changes of mothers may start when the BMI reach $25 \mathrm{Kg} / \mathrm{m}^{2}$ as the frequency of various histological changes is markedly increased in placentas of overweight mothers and considerably similar to those shown in obese group.

Study recommendation: an administration of antioxidant drugs during pregnancy to decrease the influence of oxidative stress on placental tissue and function.

\section{ACKNOWLEDGMENT}

Authors would like to thank the staff and nurses at Obstetrics and Gynecology department and Neonatal Intensive Care Unit in AL-Khansaa Maternity Teaching Hospital for their cooperation. Thanks to Dr. Luma Hazim for her help. We also grateful to assistant professor Dr. Saevan Fathil, Department of Pathology, College of Veterinary Medicine ,University of Mosul for his comments. Finally special thanks to the staff of Department of Anatomy, College of Veterinary Medicine, University of Mosul for their kind support.

\section{REFERENCES}

1.WHO - World Health Organization (2013): Obesity and overweight: http://www.who.int/mediacentre/factsheets/fs311/ en/.

2. Fitzsimons $\mathrm{KJ}$, Modder J, Centre for $\mathrm{M}$. et al. Setting maternity care standards for women with obesity in pregnancy. Semin Fetal Neonatal Med. 2010;15(2):100-107.

3.Galliano D, Bellver J. 2013: Female obesity: short- and long-term consequences on the offspring. Gynecol Endocrinol.29 (7):626-631.

4. Davies GA, Maxwell C, McLeod L et al. SOGC clinical practice guidelines: obesity in pregnancy. Int J Gyn Obstet. 2010;110(2):167-173. DOl.org/1016/j.jogc.2018.018

5.Lackey DE, Olefsky JM. Regulation of metabolism by the innate immune system. Nat Rev Endocrinol. 2016; 12:15-28.

6. Robinson, D.P. and Klein, S.L. Pregnancy and pregnancy-associated hormones alter immune responses and disease pathogenesis. Horm Behav.2016 ;62, 263-271.

7.J. Hempstock, E. Jauniaux, N. Greenwold, Burton GJ. The contribution of placental oxidative stress to early pregnancy failure, Hum. Pathol. 2003; 34: 1265e 1275.DOI:10. 1016/j. humpath.2003.08.006

8.Adam Whaley-Connell, James r. Sowers, .The Role of Oxidative Stress in the Metabolic Syndrome Rev Cardiovasc Med. (2011);12 (1):21-29

9. Jose Antonio Morales-Gonzalez, Angel MoralesGonzalez, Eduardo Osiris Madrigal-Santillan . A Master Regulator of Oxidative Stress - The Transcription Factor Nrf2 ,10.5772/62743. In: Rosangela F.F de Araujo, Danyelly Bruneska G. Martins , Maria Amélia C.S.M. Borba (2016) Oxidative Stress and Disease. 10.5772/65366

10. Mostafa Cheraghi, Hassan Ahmadvand, Ali Maleki Babaeenezhad E,Shakiba S, Hassanzadoh F. Oxidative Stress Status and Liver Markers in Coronary Heart Disease Reports of Biochemistry \& Molecular Biology . 2011; Vol.8, No.1.

11. Al-Kubaisy et al. Maternal obesity and its relation with the cesarean section: A hospital based cross sectional study in Iraq. BMC Pregnancy and Childbirth. 2014; 14:235.

12. Houben ML, Nikkels PG, van Bleek GM,Visser GHA, Rovers MM,Kessel $\mathrm{H}$ et al. The association between intrauterine inflammation and spontaneous vaginal delivery at term: a cross-sectional study. PLoS One. (2009); 4(8):e6572.

13. Khong TY, Mooney EE, Ariel I,Balmus NCM, Boyd TK, Brundler MA et al. Sampling and definitions of placental lesions: Amsterdam 
placental workshop group consensus statement. Arch Pathol Lab Med. 2016; 140(7):698-713.

14. Veerbeek JH, Nikkels PG, Torrance HL,Gravesteijn J, Post-uiterweer ED, Derks JB et al. . Placental pathology in early intrauterine growth restriction associated with maternal hypertension. Placenta. 2016; 35(9):696701.DOI:10.1016/j.placenta.2014.06.375

15. Sedlak, J.; Lindsay, R.H. Estimation of total, protein-bound, and nonprotein sulfhydryl groups in tissue with Ellman's reagent. Anal. Biochem. 1968;24, 25(1), 192-205.

16. Gilbert HS,Stump DD, Roth EF .A method to correct for error caused by generation of interfering compound during the erythrocyte lipid peroxidation analytic Biochem. 1984; 137.pp:282-86.

17. Harris $M$ and Taylor $G$. medical statistics made easy. Martin dunitz company, London, UK, 2004; pp24-29.

18. Redline RW. Classification of placental lesions. Am J Obstet Gynecol. 2015; 213(4 Suppl):S21S28.

19. Huppertz B. The anatomy of the normal placenta. J Clin Pathol. 2008 ; 61:1296-302.

20. Gill JS, Salafia CM, Grebenkov D, Vvedensky DD. Modeling oxygen transport in human placental terminal villi. J Theor Biol. 2011 ; 291:3341.DOI:10.1016/J.JTBI.2011.09.008

21. K. Devi Sankar, P. Sharmila Bhanu, Sujatha Kiran, B. A. Ramakrishna BA, Shanthi V Vasculosyncytial membrane in relation to syncytial knots complicates the placenta in preeclampsia: a histomorphometrical study; Anat Cell Biol. Jun. 2012; 45(2):8691.DOI:10.5115/acb.2012.45.2.86

22. Hayward CE, Higgins L,Cowley EJ,Greenwoods SL, Sibley CP,Wareing M. Chorionic plate arterial function is altered in maternal obesity. Placenta. 2013 ; 34:281287.DOI:10.1016/j.placenta.2013.01.001

23. Benirscheke K, Kaufmann P. Pathology of the human placenta, 2000 ; 4th edition .NewYork: springer-Verlag.

24. Olivar C Castejon S. and Angela J Lopez g. Syncytial cell surface of placental villi associate with obesity. Cell cellular Lif sci J, 2018 ; 3(2):000128.

25. Brouwers L, Franx A, Vogelvang TE, Honben ML, Rijn BV,Nikkels PGJ. Association of Maternal Prepregnancy Body Mass Index With Placental Histopathological Characteristics in Uncomplicated Term Pregnancies, Pediatric and Developmental Pathology. Vol. 2019 ; 22(1) 4552.DOI: $10.1177 / 1093526618785838$

26. Morgan TK, Tolosa JE, Mele L, Wapner RJ, Spong CY, Sorokin $\mathrm{Y}$ et al. Eunice Kennedy Shriver National Institute of Child Health and
Human Development Maternal-Fetal Medicine Units Network. Placental villous hypermaturation is associated with idiopathic preterm birth. J Matern Fetal Neonatal Med. 2013 ; 26(7):647653.DOI:10.3109/1476058.2012.746297

27. Benirschke K, Burton GJ, Baergen RN. Pathology of the human placenta. 2012 ; 6th ed. New York, NY: Springer.

28. Fox H, Sebire NJ. Pathology of the placenta. $3^{\text {rd }}$ ed. London: Saunders Elsevier. Page 2007 ; 139-141

29. Faye-Petersen OM, Heller DS, Joshi VV. Handbook of placental pathology. 2006 ; 2nd ed. London: Taylor and Francis. Page 141

30. Edinson VR,Martha RT, Ender HY, Eduardo $R V$, Jorly MM, Duly TD et al. Nucleated red blood cells and erythropoietin in overweight and obese pregnant womenProg Obstet Ginecol. 2019 ; 62 (1):26-30.

31. Barak S, Mimouni FB, Stern R, Cohen N, Marom R. Effect of maternal body mass index on cord blood erythropoietin concentrations. Journal of Perinatology. 2015 ; 35, 2931.DOI:10.1038/jp.2014.140

32. Tanaka K, Yamada K, Matsushima M, Izawa T|, Furukawa S, Kobayashi $\mathrm{Y}$ et al. Increased maternal insulin resistance promotes placental growth and decreases placental efficiency in pregnancies with obesity and gestational diabetes mellitus;J Obstet Gynaecol Res. 2018 ; 44(1):74-80.DOI:org/10.1111/jog.13474

33. Redline R. Distal villous immaturity. Diagn Histopathol. 2012 ; 18:189-94.

34. Janowiak Z, Mazerski J. New criterion of placental barrier maturity Zentralbl Gynakol. $1992 ; 114$ (6):292-295

35. Leon-Garcia SM, Roeder HA, Nelson KK,Liao $X$, Pizzo DP,Laurent LC et al. Maternal obesity and sex-specific differences in placental pathology. Placenta. 2016 ; 38:3340.DOI:10.1016/j. placenta .2015. 12.006

36. Rosado-Y|epez PI, Chavez-Corral DV, RezaLopez SA, Leal-Berumen I,Fierro-Murga R, Caballero-Cummings $S$ et al. Relation between pregestational obesity and characteristics of the placenta, The Journal of Maternal-Fetal\& Neonatal Medicine 2020 ;33(20), DOI : 10. 1080 / 14767058.2019 .1573222$.

37. Mehta R, Nanjundaswamy S, Shen-Schwarz S, Petrova A. Neonatal morbidity and placental pathology. Indian J Pediatr. 2006 ; 73(1):2528.DOI:109.1007/BF02758255

38. Redline RW, Minich N, Taylor HG ,Hack M. Placental lesions as predictors of cerebral palsyand abnormal neurocognitive function at schoolage in extremely low birth weight infants (<1 kg).Pediatr Dev Pathol. 2007 ; 10:28292.DOI:10.2350/06-12-0203.1 
39. Avagliano L, Locatelli A, Danti L ,Felis $S$, Mecacci F,Bulfamante GP. Placental histologyin clinically unexpected severe fetal acidemia at term.Early human development. 2015 ; 91:33943.DOI:10.1016/j.earlhumdev.201501. 004

40. Roberts KA, Riley SC, Reynolds RM,Evans M, Statham A, Hor $\mathrm{K}$ et al. Placental structure and Inflammation in pregnancies associated with obesity. Placenta. 2011 ; 32(3):247254.DOI:10.1016/j.placenta.2010.12.023

41. Denison FC, Roberts KA, Barr SM Norman J E. Obesity, pregnancy, inflammation, and vascular function. Reproduction. 2010 ; 140:373-385.DOI:10.1530/REP-10-0074

42. Roberts VH, Smith J, McLea SA, Heizer AB, Richardson JL, Myatt L. Effect of increasing maternal body mass index on oxidative and nitrative stress in the human placenta.Placenta. 2009 ; 30:169-175.DOI: 10.1016/ J.placenta. 2008.11.019

43. N. Malti , H. Merzouk ,S.A.Merzouk, B.Loukidi N.Karaouzene, A.Malti and M.Narce Oxidative stress and maternal obesity: Feto-placental unit interaction ;Placenta Volume, 2014 ; vol.35, no. 6, pp. 411-416.

44. Siddiqui IA, Jaleel A, Tamimi W Al-Kadri HMF. Role of oxidative stress in the pathogenesis of preeclampsia. Arch Gynecol Obstet. 2010 ; 282:469e74.DOI: s0040-010-1538-6

45. Myatt L, Cui $X$. Oxidative stress in the placenta. Histochem Cell Biol. 2004 ; 122(4):369e82.

46. Lambertucci $\mathrm{RH}$, Hirabara $\mathrm{SM}$, Silveira $\mathrm{DR}$, Levada- Pires ACL,Curi R, Pithon-Curi TC. Palmitate increases superoxide production through mitochondrial electron transport chain and NADPH oxidase activity in skeletal muscle cells. J Cell Physiol. 2008 ; 216 (3) 796804.DOI"10.1002/jcp.21463

47. Lowell BB, Shulman GI. Mitochondrial dysfunction and type 2 diabetes. Science. 2005 ; 307 (5708) 384-387.

48. Hojlund K, Wrzesinski K, Larsen PM, Fey SJ, Roepstorff $\mathrm{P}, \mathrm{H}$ |andberg $\mathrm{A}$ et al. Proteome analysis reveals phosphorylation of ATP synthase beta -subunit in human skeletal muscle and proteins with potential roles in type 2 diabetes. J Biol Chem. 2003 ; 278 (12) 1043610442.DOI:10.1074/jbc.M212881200

49. Graziewicz MA, Day BJ, Copeland WC. The mitochondrial DNA polymerase as a target of oxidative damage. Nucleic Acids Res. 2002 ; 30 (13) 2817-2824.

50. Lurba E, Gratacós E, Martín-Gallán P ,Cabera L, Dominguez C.A comprehensive study of oxidative stress and antioxidant status in preeclampsia and normal pregnancy. Free Radic
Biol Med. 2004 ; 37 (4) 557-570. DOI:101016/j.freeradbiomed.2004.04.035

51. Mele J, Muralimanoharan S, Maloyan A, Myatt L. Impaired mitochondrial function in human placenta with increased maternal adiposity. Am J Physiol Endocrinol Metab. 2014 ; 307 (5)E419E425.DOI:10.1152/ajpendo.00025. 2014 